Prepublished version. For final version and citations:

Ergas, O. (2017). Reclaiming ethics through "self": A conceptual model of teaching practice. Teaching and Teacher Education, 68, 252-261.

\title{
Reclaiming ethics through "self": A conceptual model of teaching practice
}

Oren Ergas

Beit Berl College, Israel

\begin{abstract}
:
Higher education institutions have been accused of losing their moral orientation and failing to provide students with a meaningful educative experience. This paper exposes the roots of this problem within contradictions between two historical commitments of higher education: "serving science" and "know thyself". The paper then develops a conceptual model of teaching practice as such. The model demonstrates the predominance of "serving science", which leads to the compromising of ethics and meaning. The model is then developed to show how "self" can be explicitly reclaimed by integrating the two epistemologies-ethics in teaching practice. Contemporary pedagogical examples are presented to demonstrate this approach.
\end{abstract}

Keywords: teaching, science, know thyself, ethics, higher education, contemplation, knowledge, pedagogy 
We are cheating our students out of the opportunity to inquire deeply into their own meaning and find themselves in the center of their learning, thus providing them with a clear sense of the meaning of their studies. (Barbezat \& Bush, 2014, p. xv).

\section{Introduction}

In the passing decade higher education has been subject to unabated critique, which can broadly be located as a "moral crisis". As Harry Lewis (2007), former Dean of Harvard College, starkly argued: Universities have forgotten their larger educational role for college students. They succeed better than ever, as creators and repositories of knowledge. But they have forgotten that the fundamental job of undergraduate education is to...help [students] grow up, to learn who they are, to search for a larger purpose for their lives and to leave college better human beings. (p. xii)

Lewis's statement positions us at the heart of what may be a central aspect of this moral crisis, to which I will refer as the bifurcation between "serving science" (i.e., discovering/creating "knowledge") and "self". It seems that somehow "knowledge", as we have come to understand it, has been separated from educational ideals that have to do with what it means to be a person in the world, to seek purpose, meaning, goodness, and connection with others. Expressions of this dichotomy appear frequently in critical accounts of Higher Education, which is construed as training students, "to divorce their rationality from the rest of themselves" (Simmer-Brown, 2009, p. 98), educating "from the neck and up" (Lelwica, 2009, p. 125), and treating the student as a "brain on a stick" (Lewis, 2007, p. 100). William Deresiewicz (2014) expressed this crisis through accounts of students who attend ivy-league Universities, yet hide a sense of meaninglessness with the aid of stimulants and anti-depressants (p. 9). In Business undergraduate programs, the most commonly 
studied in the US, students claim that their courses teach that "'everything is business - overlooking the different values represented by their families, religious congregations, and communities" (Colby, Ehrlich, Sullivan \& Dolle, 2011, p. 5). The image of the graduate that emerges from these harsh accounts seems to result as the "bifurcated educated person" who in the course of his or her studies, learns that Higher Education and a search for meaning in life, do not belong under one and the same roof.

Some would argue that these are symptoms of contemporary times in which economic thinking has been taking over education (Gilead, 2012), transforming Higher Education institutions into marketplace players (Bok, 2009), and tying them with economic success in ways that jar against fundamental concerns of Liberal education (Deresiewicz, 2014). Demonstrating the case of UK, Gert Biesta (2009) frames this economic orientation within the "outcomes" discourse that manifests in the "'learnification' of education": "the translation of everything there is to say about education in terms of learning and learners" (p. 38). For Biesta this progression leads to a disappearance of questions concerned not only with what pupils and students learn, but also with "what they learn it for" (p. 39).

These systemic and external contemporary conditions surely have something to do with this moral crisis; however, reading Nietzsche's $19^{\text {th }}$ century critique of his contemporary Academia, reveals that the bifurcation between "self" and "serving science" is no novelty of contemporary times:

Men [and Women] of learning set about their scientific pursuits reveal above all that they are thinking more of science than they are of mankind, that they have been trained to sacrifice themselves to it like a legion of the lost, so as in turn to draw new generations on to the same sacrifice. (1997, p. 129) 
There seems to be something that is more deeply engrained in the academic lecture hall (and perhaps in school classrooms), which perpetuates the sense that education is about providing "knowledge", but not a sense of why this "knowledge" has meaning for you or for me at a personal level. Nevertheless, many students arriving at the gates of Higher Education do expect these institutions to offer both for they come, "seeking not only knowledge but a sense of meaning and purpose" (Palmer, Zajonc \& Scribner, 2010, p. 4). Higher Education institutions themselves seem to promise them a meaningful experience, but as Barbezat and Bush (2014) claimed:

Somehow we have lost our way in higher education and abandoned our mission to create lives of purpose and strong ethical and creative minds. Look at any university or college's mission statement and you'll see they are filled with that sort of rhetoric. However, in the actual education, where does it happen? It mostly does not. (p. xv)

If Lewis pointed to the bifurcation between "knowledge" or "serving science" and "self", Barbezat and Bush further articulate what I take to be a root-cause of our moral crisis - the notorious gap between what we say about education and what we do when it gets to educating - the gap between theory and practice (Ergas, 2017a). The critical and unpleasant accounts brought above do not apply to all lecture halls, to all institutions or to all lecturers and students, but their pervasiveness is disturbing and cannot be ignored. This paper is a methodical investigation of these two bifurcations: "serving science" and "know thyself", "theory" and "practice", and their interconnection; how they may have emerged, how they are reflected in practice, and possibly, how they can be addressed.

Notwithstanding systemic and economic external conditions, this paper suggests that our moral crisis can be diagnosed within teaching practice. While views expressed by critics and by students about Higher Education are formed based on diverse aspects of the academic life, the lecture hall has a significant place in shaping the academic experience. This paper focuses on examining how teaching practice can wittingly or unwittingly create the bifurcated image of Higher 
Education. Here this will mean moving from an examination of what we teach, to how we teach. This movement is about exploring how the act of teaching always reflects aspects of: (a) Epistemology what counts as "knowledge", entangled with (b) Ethics - the role of "self" in the "knowledge".

The paper explores this entanglement in two steps. In the first part, I offer a historical excursion that explains Higher Education as rooted in two epistemological commitments: "know thyself" and "serving science". As I will propose, our moral crisis emerges because the ethos of "serving science" has been adopted by our teaching practice, leading to the expulsion of "self" from the lecture hall. The price we pay for this is the loss of a serious education in morality, agency and meaning that mobilizes students from compliance with social consensus, to a personal engagement in the creation of meaning within the social sphere. The paper then moves from this historical analysis to a conceptual exploration of teaching practice as such. It demonstrates how epistemology and ethics appear at the very nitty-gritty moment-to-moment act of teaching regardless of subject matter and regardless of students' age. This is developed into a conceptual model that stems from the faculty of attention, and enables us to explore the four possible modalities of teaching and the role of "self" within them, which are all necessary for an integrated Higher Education. The second part of the paper will explore how "self" can be reclaimed in teaching. While in this paper I refrain from proposing specific guidelines based on the model developed, I will offer various contemporary examples, which demonstrate that the epistemic-ethical commitments to "serving science" and to "know thyself", can be fruitfully integrated. The paper ends with critical comments in regards to its proposal.

\section{Two epistemologies of Higher Education teaching}

A bistorical perspective 
Very roughly, I argue that we can find two kinds of epistemologies-ethics in the conception of higher education when we examine it from a historical perspective. The first is the ancient DelphicSocratic "know thyself". This ethos and its importance have been expressed in dialogues written by Plato, known as the founder of Academia. In the Phaedrus, Socrates - Plato's teacher and protagonist - explicitly claimed, "I am still unable, as the Delphic inscription orders, to know myself and it really seems to me ridiculous to look into other things before I have understood that" (229e-230a). Charles Taylor elaborated this ethos and suggested that, "[t]o know who you are is to be oriented in moral space, a space in which questions arise about what is good or bad, what is worth doing and what not, what has meaning and importance for you and what is trivial and secondary" (1992a, pp. 2728), and later, "[w]e are selves only in that certain issues matter for us. What I am as a self, my identity, is essentially defined by the way things have significance for me..." (1992a, p. 34).

Taylor's interpretation of "know thyself" points clearly to at least three ideas: morality, meaning, and agency (i.e., my willing my actions and my being responsible for them). It also points to a clear pedagogical injunction:

An education that aspires to help students find meaning in what they do and become moral citizens, must include their engaging with their own "selves" deliberately.

Pierre Hadot (1995) demonstrated how "know thyself", was expressed in diverse Greco-Roman schools of thought, which both developed and critiqued Socratic ideas. The practical orientation of these schools of thought was that "self-knowledge" is key to the cultivation of a life of meaning and virtue. An education that hopes to cultivate these qualities cannot but depend on a deep respect for introspection and for "self" as an orientation in which, "we come to think of ourselves as beings with inner depths" (Taylor, 1992b, p. 26, emphasis added). "Self-knowledge" can thus be considered to be a "curriculum" in its own right. It unfolds within a pedagogical space in which meaning becomes 
personal meaning within a social sphere and moral action becomes a deliberate choice rather than blind dogma.

Interestingly, the second source of epistemology-ethics of higher education can be understood to emerge from Plato's writings as well. Here, I am alluding to the ethos of objectivity when taken perhaps to its extreme position, as arriving at Absolute truth that is independent of the knower. In Plato this was reflected in the world of forms most notably expressed in the cave allegory (Republic, book 7). However, it received its clearest expression in the $17^{\text {th }}$ and $18^{\text {th }}$ centuries with the founders of the epistemology of modern science. As Richard Rorty (2009, p. 12) claimed, the philosophers of this epoch, were held captive by the picture of the mind as a great mirror, which once repaired and polished would provide us with an accurate representation of nature. A hard-core conception of "knowledge" in this sense then, suggests that the less of "self" (i.e., the knower) exists in the knowledge, the true $r$ it becomes. In simple terms, our knowledge of gravitation, the structure of the atom, the biological markers of a heart attack or the amount of cement required for building the foundations of a skyscraper, should not depend on the sense of meaning or morality of the person who knows and applies them.

When juxtaposing these two commitments we can see how Higher Education would want both yet immediately face self-contradiction. The former "know thyself" represents an ethos that is fundamentally entangled with "self" - an enigmatic, unpredictable, uncertain, and perhaps impossible-to-grasp "entity". It aims to serve moral living, cultivate agency, and a sense of personal meaning within society. The latter epistemological position focuses on knowing "world" through scientific rigor. Its aim is certainty, which is clearly necessary for practical reasons and sometimes even for our mere survival. Each ethos appears to suggest a very different conception of "knowledge" and its association with "self". This contradiction can be bluntly posed using metaphors that appeared above: 
"Know thyself" treats us as having "inner depth" (as Taylor mentioned), whereas "serving science" treats us as flat surfaces - mirrors. Roughly, this latter orientation can be described as "know thy world, and leave yourself out of it".

However, posing things this way is disturbing for at least two reasons: first, the positivistic rendition of "serving science"; i.e., "know thy world and leave yourself out of it", which perhaps reached its peak in $19^{\text {th }}$ century Comtean positivism, is hardly held by scientists nowadays. Post-positivism (e.g. Kuhn, Popper), constructivism (e.g., Piaget) and qualitative research methods - all reflect an epistemology that construes knowledge as fully dependent on the knower (Denzin \& Lincoln, 2011). Second, the endeavor of "serving science" itself can be a deeply personal and transformative one. The image of the scientist as some "cold" disembodied being devoid of "inner depth" hardly holds when reading accounts of Goethe's or Albert Einstein's conceptions of "serving science" (Zajonc, 2006). Where then, does the problem lie? - I argue, that such understandings, which appear to reflect the integration of the two epistemologies, might be practiced in how we do research ("serving science"), but usually not in what and how we teach. If you consider lecture hall teaching - where much of the activity of Higher Education actually happens - it is governed far more by "know thy world and leave yourself out of it" - and there, I argue, lies our moral crisis. Exceptions clearly exist and some will be presented in part two of this paper; however, students' personal search for purpose and moral concerns, are rarely intentionally invited into the lecture hall. It may arise within their spontaneous inner responses to the subject matter taught, but in most cases it is not an explicit curricular orientation. "Know thyself" is mostly left for students to figure out outside the lecture hall. Applying Eliot Eisner's (1994) terms: "self" is a null curriculum - that which we do not teach and perhaps is even absent from curricular-pedagogical deliberations (Ergas, 2017b).

It would be hard to trace exactly how "serving science" has taken over "know thyself" in teaching. Perhaps we have come to associate rigor with "serving science" and "sticking with the facts" 
given that it seems to provide far more certitude than that blurry and indefinite space called "know thyself". The problem is that "sticking with the facts" deprives us of the "self" that gives them personal meaning. Setting aside the crucial need to learn the facts, what seems to be missed, is that "leaving self out of the knowing" does not mean that teaching becomes ethics-independent as if objectivity (a dubious concept as such) can be transposed to the world of teaching practice. It is simply an epistemology-ethics of another kind as expressed by Parker Palmer (1983): "[t]he way we interact with the world in knowing it becomes the way we interact with the world as we live in it....our epistemology is quietly transformed into our ethic" (p. 21).

Wittingly or unwittingly, the more we accentuate an ethos of "know thy world and leave yourselves out of it" in teaching, the more we "bring out" (as the Latin for educare) "selves" that become aliens in their own bodies and their societies. Following Taylor, take away "know thyself" as an explicit invitation within teaching practice, you cannot but leave personal meaning, agency, and morality to chance. That is, if students will engage with such issues, it would be accredited to their own efforts, and not to Higher Education institutions. The critical accounts brought above suggest that this does not happen enough as we would hope. No less, it appears to be a promise Higher Education Institutions make. Ought it not be kept?

The point made has nothing to do with the merits of science and research. It has to do with teaching (science or any other discipline). The ethics of teaching proposed here, stems from both commitments of higher education, and relies on the assumption that humans are meaning-making and meaning-seeking beings (Frankl, 1985). On this view, even when students attend courses called "Principles of Pathology", "Mechanical Engineering" or "Mixed Research Methods II", these are still nested within this greater search - a search that cannot be fulfilled without attending to "self" as an agent that gives meaning (Taylor, 1992a). Though some lecturers may feel that they are only there to teach the facts and ways of thinking in their discipline (i.e.; "serving science"), such disposition 
might hold for them but not necessarily for their students. It appears that once we step on the pedestal and open our mouths to teach/lecture in an institution we call "higher education", along with "serving science" we seem to be responsible for teaching "know thyself". We may wittingly or unwittingly ignore this yet the role seems to be tacitly assumed by many meaning-seeking students, and by the explicit statements made by our institutions themselves (which reassert these students' expectations). The question then is not whether or not "know thyself" belongs in the lecture hall, but rather what does it mean? And how can it be taught?

The following is not a recipe. It is, however, an attempt to address this practically by shedding light on teaching practice as a constant an inevitable deliberation between the two epistemologies-ethics of education. This perspective opens possible ways to engage practically in "know thyself" as the paper develops gradually.

\section{A pedagogical perspective on teaching practice}

In the following, I put the historical perspective "on hold" for a short while, and explore the fundamentals of the act of teaching as such. I suggest that we can think almost as theoretical physicists about the fundamental possibilities that are available to any form of curricular-pedagogical practice whatsoever. The result might be schematic, but I think it provides us with a powerful conceptual model for theorizing and understanding teaching as such, which can later be tied to the historical perspective offered above. I develop this based on three steps, which then lead to a conceptual model of teaching:

(a) Attention as the fundamental of teaching: Following William James (1983) and Ellen Langer (1997), we can argue that a most basic practical act of teaching is the orienting of the 
learner's attention to a certain subject matter. If the learner's attention is not oriented to the subject matter, teaching as a conventionally understood intentional act, will not occur.

(b) There are only two broad places to which one can attend at any given moment: in or out. ${ }^{1}$ As Taylor (1992a, p. 111) argued, we all seem to localize everything in the world in terms of "insideoutside" (see also James (2007, p. 187)). That is, one can either attend to one"self" to experience one's body-mind perceived as "inside" within thoughts, sensations, emotions, etc., or one can attend to what one perceives as "outside" and experience "world"; e.g., objects, the environment, other human beings. $^{2}$

The result of (a) and (b) is:

(c) There are only two basic deliberations in teaching at any given moment: orient students to attend in or out. I call this meta-pedagogy. It is a way of teaching - a pedagogy - that we cannot help but deploy, in every single moment in which we teach. Simply put:

If what you do is called "teaching", then in every given moment you are implicitly asking the student to do one of two things: attend in or attend out.

For example, showing a Powerpoint slide or describing its content based on frontal lecturing, means for the student: attend out. Asking students to ponder the validity of your explanation or its implications to their lives means for them: attend in. It doesn't matter at all whether you teach Biology, Law, Sociology, or Business management. Every single moment in a classroom grants you with only two possibilities.

\footnotetext{
${ }^{1}$ Neuroscience demonstrates that attending in and out corresponds with two systems that do not normally co-activate (Immordino-Yang, 2016).

2 This is not an ontological statement; only a phenomenological observation about day-to-day perception.
} 
It's as if a student's mind stands at a T-junction. Whether you're aware of it or not, your teaching is a constant deliberation telling students where to orient attention.

Supposedly, this is "just" pedagogy. However, I argue that this is where the epistemologyethics of teaching practice are hidden to yield the raison d'etre of education. Why? - Because the cumulative effect of these moments determines the place of "self" in our conception of "knowledge", and in education writ large. Eventually a student's formal education amounts to a concatenation of moments of attention spent in and out. These moments become years spent in lecture halls (and schools) and assignments that accompany them. In the end, there's a balance there between moments in which the student was asked to attend in, or out. Let's take this to the extreme as a thought experiment:

If all moments were spent out - we would get an education in "know thy world and leave yourself out of it". If all were spent in, we would get "know thyself and leave your world out of it".

\section{Neither works.}

Nevertheless, if we were to sample lecture halls across Higher Education institutions and register deliberations made by lecturers at this attentional level, I suspect it would be easy to demonstrate that we are quite close to the former orientation. This implies that "self" - the locus that is indispensable for education in meaning, agency and morality - is lost. We tend to miss this because we often conduct curricular deliberations (Schwab, 1969) by leaping to questions such as "what knowledge ought we teach?" Yet this almost immediately nullifies "self". We end up with a curriculum framed as "Humanities, Natural and Social sciences". We may assume that "self" is somehow included in them, but as will be demonstrated, "self" - as a living being - can only become part of the explicit curriculum through pedagogy; i.e., if we attend to it deliberately here and now. 
Again, this does not exclude the possibility that students' attention will turn in spontaneously to yield insightful "self-knowledge" (Immordino-Yang, 2016). This probably occurs throughout lectures and students' struggles with assignments outside the lecture hall. However, given this paper's attempt to address the "theory" /"practice" bifurcation - what we say about education and what we do when educating - if this turning in is not explicitly invited through our teaching practice then neither we, nor the Institutions in which we teach, can be given credit for it.

Moving toward a structured way of organizing these ideas, I argue that missing from our view are two far more fundamental questions than "what ought we teach?" Each grants us with two options, which allow us to combine the historical and the pedagogical perspectives:

1) "Where is the knowledge of most worth to be found?" - Two options: "self" or "world", which in the historical perspective imply: "know thyself" or "know thy world". 3

2) "How ought the student to engage with the knowledge of most worth?" - Two options: attend in or attend out

These two questions and their answers can be organized to yield the following conceptual model (Table 1). It is presented here conceptually, which means that I will explain and exemplify it, but I will not offer practical guidelines on how to translate it into practice, a task left for a future project.

\footnotetext{
3 "Know thy world" includes both knowing one's discipline (e.g. physics) and being able to place the discipline in a broader context.
} 


\begin{tabular}{|l|l|l|}
\hline Where? & World (know thy world) & Self (know thy self) \\
(moweta-pedagogy) & & \\
\hline Attend out & (a) Attend out - know world & (c) Attend out - know self \\
\hline Attend in & (b) Attend in - know world & (d) Attend in - know self \\
\hline
\end{tabular}

Table 1: A conceptual model of teaching practice

This model presents what seem to be the only four possible teaching acts at any given moment regardless of discipline, student age, or type of institution (e.g., school, University). It is a matrix that positions meta-pedagogy (i.e., orienting attention either in or out) against its result for that moment (i.e., either know thyself or know thyworld). The overall claim is that, set aside the subject matter, choosing to orient a student out or in, a lecturer/teacher is teaching where the "knowledge of most worth" lies for that moment and how it is worthwhile to engage with it.

We can explore this at a micro-level of moment-by-moment teaching practice during a specific lesson, or at a macro-level, when thinking of an entire course, an entire BA/MA, or even $\mathrm{K}$ through K-12. Let's begin by exemplifying each of the four possibilities at the micro-level, using the letters in each box in table 1:

(a) Attend out there to "know thy world", can manifest for example, in asking students to read a passage in the history book, look at the map of England, watch a TED lecture, listen to the teacher 
or engage class discussion. All of these activities require that students attend out to external objects/events.

(b) Attend in bere to "know thy world", can manifest in asking students to reflect on the history passage, assess the population density in England, critique the argument made in the TED lecture, or think of a response to the teacher's question. All of these activities require that students attend in to consider external objects/events.

(c) Attend in here to "know thyself", can manifest in asking students to write a journal, meditate, attend to their breaths or to their personal thoughts, reflect on the meaning of their existence, or explore their bodily reactions as they engage in dialogue with others about any subject. All cases require attending to one's inner experience and treating it as curricular content.

(d) Attend out there to "know thyself", can manifest in asking students to read a passage in a history book in order to reflect on the personal meaning of the events, look at the map of England and imagine yourself living there, or contemplate the relevance of the points made in the TED talk to your own life-circumstances. In each of these cases the purpose of attending out is to engender a "bringing out" of "self" and connecting "self" to "world" at a personal level.

The micro-level proposes meta-pedagogical "snapshots" of teaching practice from the perspective of attention. If you took many snapshots within one lesson, or hundreds during an entire semester/year, you would get the macro-level. This would give an overall image of the place that "self" is given in relation to the "knowledge" taught; i.e., epistemology's entanglement with ethics in teaching practice. The following discusses this macro-level:

A lecturer asked to teach a certain discipline (e.g., Math, Architecture) would usually follow (a) \& (b). If this is a large introductory course (e.g., History of Western civilization, Introduction to psychology), s/he might rely heavily on (a) (e.g., frontal lecturing) and maybe occasionally deliberately apply (b) (e.g., asking questions). I argue, however, that teaching "know thyself" 
deliberately, can never occur without (c) \& (d), which are too rare in our institutions. Again, this is not a question of what we teach but rather of how. As later elaborated, even the teaching of subjects that are seemingly remote from "know thyself", such as Economic theories, can be taught meaningfully by, for example, incorporating a meditation on compassion, which makes students realize that their "cold" decision making is fully entangled with their emotions (Barbezat \& Bush, 2014, pp. 51-66). Conversely, a subject such as "theories of self", which supposedly lends itself to (c) and (d), can be taught with utter disregard to the living students' "selves". If all students are asked to do is review Jamesean, Freudean, Jungean theories about the "self" in a psychology course, or study about Socrates's attempts to know "his" "self" without actually exploring their own, in a philosophy of education course, then "self" becomes an object that has little relation to their own existential concerns. The gap between theory and practice lies then and there for they surmise that theories about life are somehow superior to living. An intentional deliberate engagement in "Know thyself" would require, for example, that students validate or challenge James's theory of "self" based on examining their own "self" and comparing their conclusions with others.

Another point to be clarified that will help understand the above four possibilities, is that categories (c) and (d), to which I dedicate the next part of the paper, ought not be collapsed simply to constructivist approaches to teaching and learning. Constructivism is far more nuanced then can be fully acknowledged here (Phillips, 1995); nevertheless, "know thyself" does not necessarily stand at their center, even if we sometimes like to think that way. Constructivist approaches, reflect diverse teaching epistemologies in which meaning and understanding are considered to happen in the mind of a student as a consequence of his/her integrating new knowledge into existing schemes of prior understandings (Perkins, 1999). The ethics of this approach will clearly be reflected, for example, in lecturers'/teachers' giving precedence to asking questions and reflection over frontal lecturing, yet the determining question to ask is - what would be the content on which the students will reflect? If that 
content is eventually the subject matter of "world" then maybe this is "know thyworld and surmise that you are involved in the knowing of world", yet the knower - "self" - still remains outside of the game. In other words, constructivism alone is more of a movement from (a) to (b). This might be a highly meritorious practice, which may well lead to engaged learning, but it does not necessarily yield "know thyself" explicitly.

In the next part of the paper, I focus on what it means to reclaim "self" into our teaching practice and how this reclaims meaning and ethics. Before proposing this elaboration, it is important to claim that I am not arguing that Higher Education is meaningless. It is certainly meaningful, yet the meaning given to it as reflected in common teaching practice, is given by society and not by the individuals that eventually study the subject matter that society had deemed meaningful. As Biesta (2009) suggested, education includes three functions: qualification, socialization and subjectification, the latter of which I associate with "know thyself". Many such as Dearden, Hirst and Peters (1972) would argue as Biesta argued "that any education worthy of its name should always contribute to processes of subjectification that allow those being educated to become more autonomous and independent in their thinking and acting" (2009, p. 41). If we hardly turn students inward to explore their own minds and bodies, what is left, is socialization and qualification. As I argue, a metapedagogical turn inward evokes the "self" that gives meaning at the individual level. It is only then that a student actually becomes a conscious moral agent, who participates in the re-validation or challenging of our social inter-relational practice of creating meaning.

\section{"Know thyself": Curriculum, pedagogy and teaching}

There is no attempt here to suggest that "self" lends itself to a clear and systematic curriculum, or to some "structure of knowledge" (Bruner, 1977) that offers a definite organizing framework by which it can be studied. Socrates's statement from the Phaedrus, brought above, certainly shows that "self" 
is a mystery and philosophers and poets across cultures and historical periods expressed this mysteriousness in diverse ways (Shusterman, 2012, ch. 3). My intention then is to express a curricular-pedagogical orientation allowing for creativity that emerges from lecturers'/teachers' own "selves". At the same time, I will bring practical examples to ground this orientation. Broadly, I argue that if higher education is to rise up to its own occasion, then the epistemology-ethics of teaching must stand on a balanced meta-pedagogy that includes all four possibilities. We have been leaning too heavily on "know thyworld", implying a meta-pedagogy that relies on (a) \& (b) (table 1). My aim here is to further articulate what a curricular-pedagogical approach that incorporates categories (c) and (d) implies in theory and practice.

First, it is important to articulate that pedagogies that require students to attend to their own minds have certainly been described in academic publications and are applied in practice. Most notably, reflection - as a practice that depends on an attention that is turned in deliberately - was central to John Dewey's pedagogical approach (Rodgers, 2002) and has become a discourse in its own right that has its expressions across fields (Schon, 1987). Nevertheless, if the purpose of reflection remains practical problem solving in which things out there are prioritized, then as in the case of constructivism, "know thyself" might result only as an occasional by-product of such process. This hardly debunks the great value and the necessity of reflection. It is only meant to clarify the educational ethos we promote by introducing reflection in courses. Only if reflection is intentionally pushed from solving technical problems to questions like: "what meaning does this problem have for me?", "what kind of problem solver am I?", "what personal and social meaning does my solution bring about?", "How am I promoting a just and kind society based on it?", and most importantly "who am I and how am I connected to you?" - does "self" become an end in its own right and not merely an instrument. 
The kind of meta-pedagogical turn inward that I am suggesting follows others such as Pinar and Grumet (2014) in positioning "self" explicitly at the center of curriculum and pedagogy, even if for brief intermissions within lectures and classroom teaching. This begins by taking Alfred North Whitehead's statement, "[t]here is only one subject-matter for education, and that is Life in all its manifestations" (1967, p. 10) with utter seriousness. I interpret it to mean that our inner experience is an integral part of the "manifestations of life", and these should count as subject matter, in fact, an inner curriculum (Ergas, 2017b). Students might choose to study Law, Physics, Sociology, Psychology, or any other specific discipline, yet not even one of them will find a way to escape the subject matter of their unfolding "selves" throughout their entire lives. It will appear to them in their thinking, emoting, sensing, yearning, intuiting, hating, loving, wanting, needing, caring, reacting, responding... all those faculties of minds-bodies and the content experienced within them in the lecture hall and outside it. The latter constitute subject matter that we; students and lecturers alike, face throughout life from moment to moment as we seek meaning and purpose.

The nature of this "subject matter" is not comparable to the nature of subject matter as we have come to think of the term, for it is in a constant flux and can hardly be pinned down and grasped in the same sense that factual knowledge or a certain skill can be grasped. Nevertheless, our lives are a constant grappling with this "subject matter", which is unique, diverse, and to which only $w e$ - as students as lecturers - have access, as Barbezat and Bush (2014) claimed: "[n]o matter how radically we conceive of our role in teaching, the one aspect of students' learning for which they are unambiguously sovereign is the awareness of their experience and their own thoughts, beliefs, and reactions to the material covered in the course" (p. 4). The question then, is how does Higher Education respond to this manifestation of life that is there present in the lecture hall and outside it throughout one's life? 
The suggestion here is that when approaching "know thyself", we need not compromise the standards of scientific rigor at all. Rather, we need to apply this very rigor to knowing ourselves. As Harold Roth, head of Brown University's Contemplative Studies concentration, claimed: "[w]e have become the masters of third-person scientific investigation, but we are mere novices in the arts of critical first-person scientific investigation" (2006, p. 1787). The very scientific minds that we have been applying throughout the development of modern science toward refining our methods of "serving science", can be applied with rigor to "know thyself". As will be demonstrated, these two epistemologies of higher education can be integrated to enhance each other. The reclaiming of meaning and ethics to the educational experience, cannot but rely on the inclusion of the "self" as it appears to the "self" in all its manifestations (Pinar \& Grumet, 2014; Whitehead, 1967)- body and mind; sensations, thoughts, emotions; and should the case be that there are other manifestations, then those should be included as well. It is to be clarified, however, that "know thyself" is not detached from "knowing world" and living in it. Both hinge on a "door of attention" that swings constantly in and out to construct our experience (Ergas, 2017a,b). However, given the neglect of this domain, "know thyself" needs to be clearly defined and studied intentionally as a distinct part of a broader curriculum that merges the two commitments of Higher Education. The following is a possible way of defining this curricular orientation followed by a section of the paper that demonstrate its practice:

Deliberate education in "know thyself" is the practice of orienting students explicitly to examine their inner experience intentionally and mindfully; to explore the unfolding "inner curriculum" to which only they have access, and the ways in which they make meaning based on it and based on the knowledge that they are taught in courses. It is to help them find their way in the incertitude of embodied life, seek purpose, and engage meaningfully and morally with others. 


\section{What does this mean in practice?}

Every time we note our thoughts or bodily sensations, is the result of an attention that was spontaneously or intentionally drawn in. Yet, despite the great chunks of time we spend in, we do not tend to consider much of the content we encounter there as something that is worthy of our attention. In Dewey's word: "[M]ore of our waking life than we should care to admit, even to ourselves, is likely to be whiled away in [...] inconsequential trifling with idle fancy and unsubstantial hope" (1997, p. 2). Indeed, these spontaneous inner "sessions" lack the mindful deliberation to which I refer when speaking of pedagogies that reflect categories (c) and (d) developed above. When addressing these categories I speak of an intentional engagement with ourselves and there are diverse frameworks within which to nest such meta-pedagogical turn in. Some of these frameworks are more likely to be widely accepted and safely offered publicly in Higher Education Institutions. One framework that seems promising stems from the discourse of contemplative practices. Contemplative practices are increasingly being incorporated in education, much to the credit of the developing field of contemplative science, which concerns the study of the effects of these practices on brain plasticity, subjective well-being, health, performativity, and human development (Farb, Segal, \& Anderson, 2013; Garland, Farb, Goldin, \& Fredrickson, 2015; Roeser \& Peck, 2009; Roth, 2006; Tang, Hölzel, \& Posner, 2015; Wallace, 2000; Zenner, Herrnleben-Kurz, \& Walach, 2014).

A robust definition of contemplative practices, which reflects the integration of the two epistemologies of education, was offered by a group of twelve leading neuroscientists, psychologists, educational scholars and practitioners. They defined contemplative practices as, forms of mental and behavioral training that are intended to produce alterations in basic cognitive and emotional processes, such as attention and the regulation of certain forms of 
negative affect, and to enhance particular character traits that are considered virtuous, such as honesty and kindness... A defining characteristic of such practices is that they require individuals to exercise volitional control to sustain the focus of attention on particular objects (such as the breath) or mental contents. (Davidson et al., 2012, p. 147-148). This definition includes two components that are crucial to the point made in this paper: (a) an epistemology that emerges by including a meta-pedagogical turn of attention in to students' inner experience; (b) an ethical orientation concerned with the cultivation of virtues. These are practices in which one turns one's attention deliberately in toward one's sensations, thoughts and emotions, with a disposition of curiosity and detachment that may well reflect how a scientist engages in research; only in this case, she is both the subject that conducts the research and the "object" of research. This pedagogical orientation opens a broad terrain of possibilities, which is reflected in another definition of contemplative practices - one that offers an additional framing for this discourse: contemplative practices are "ways that human beings, across cultures and across time, have found to concentrate, broaden, and deepen conscious awareness as the gateway to cultivating their full potential and to leading more meaningful and fulfilling lives" (Roth, 2006, p. 1788).

These two definitions reveal that contemplative practices can be framed both through a scientific perspective, based on measurable, concrete and operational terms (e.g., sustained and focused attention) and through a perspective that highlights the heritage of cultures across the world, which appeals to a crucial ethics of diversity and inclusion. Such ethics propose that the Socratic philosophical tradition is a formidable path surely to be cherished; nevertheless, additional paths toward "self-knowledge" have emerged from East-Asian, Native American, Aboriginal, African-American and other cultures as well (Barbezat \& Bush, 2014; Merculieff \& Roderick, 2013). The developing discourse of "contemplative pedagogies" - contemplative practices that are applied within educational institutions toward diverse educational aims - is becoming a rich and 
vibrant educational arena within which the above orientation can be practically demonstrated. A series of recently published books and edited volumes reflect the growth of this field, its diversity and its growing legitimacy in higher education (Barbezat \& Bush, 2014; Berila, 2015; Gunnlaugson, Sarath, Scott \& Bai, 2014; Lin, Oxford, \& Brantmeier, 2013; Palmer et al., 2010). The following four examples very briefly demonstrate creative ways in which lecturers in diverse disciplines adopt a meta-pedagogical turn in to "know thyself":

1. Communication: At the University of Washington, communication students study technology and the way in which it shapes their personal day-to-day habits. Lecturer David Levy (2016) developed diverse pedagogies for this purpose, such as students' filming themselves working on the computer, exploring what makes them open Facebook while they are supposed to be working on an assignment, and observing their inner-experience as they go about their daily routines of checking email, texting, and using social networks. All these practices are designed to help students expose their unwitting behaviors and choices. As Levy describes, this course often brings insights into their lives, leading them to make meaningful choices in regards to their social interactions and technology use.

2. Neuroscience: Levit Binnun and Tarrasch (2014) describe an undergraduate course in brain theory for psychology students in Israel in which Levit-Binnun incorporates "personal braininvestigations". These are pedagogies that she designed in which theoretical concepts of brain theory (studied via mode (a)), are also studied by students' bringing their attention to their own bodies. For example, a student will turn attention in, to investigate "how does my brain select stimuli to shape my experience?" and "how does this affect my social interactions?" Through these practices, "a brain" presented on the Powerpoint slide out there, becomes my brain and yours, here and now. 
3. Law: Rhonda Magee (2016) describes a set of mindfulness and compassion-based practices, which she introduces in her Law teaching. The aim of Magee's meta-pedagogical turn inward is to engender embodied "ColorInsight" - a socially-engaged awareness to our deep-seated racial biases. "Knowing thyself" in this case, is a relational practice by which students examine how their own mind can impede on their ethics of diversity and inclusion and affect the public practice of Law and justice. Through these practices Magee proposes that students also work to develop the inner stamina required for engaging in social change.

4. Academic writing: In their study, Solbrekke and Helstad (2016) demonstrate how a teacher educator manages to leverage the teaching of academic writing - an area of struggle for many students - to invite preservice Norwegian teachers into an exploration of the deep ethical commitments of teaching. Focusing on themes such as the aims of education and the character of a teacher, while insisting on the highest standards of writing, he manages to fuse professional education, academic skills and character formation. This can sometimes include provocative strategies, such as asking his students, "Are you sure you want to work as a teacher? Because this is not a job for everyone" (p. 970).

These examples are a fraction that represents category (c), in which subject matter of "world" becomes the object against which "self-knowledge" unfolds. The rigor of science here, is not compromised but perhaps enhanced. These examples also respond to possible critical claims, which would view this turn to "self" as somehow accentuating ego-centrism or a turning away from society. Quite the contrary, a deeper examination of the above books/papers will reveal that these lecturers' turn to "self" stems from an uncompromising ethics of care for the other, which they seek to cultivate in their students through these practices. The epistemology-ethics behind their approach suggests that it is only through growing awareness to my own "inner depth" that my agency can become integrated with morality and intelligence and manifest in my relationships with others. 
A (d) orientation would go even farther than this. In Parker Palmer's (1998) writings on teacher education, we find this emerging as a gradual movement from externally to internally oriented questions; from "what shall we teach?" to "how shall we teach?", "why do we teach", and finally, "who is the self that teaches?" (p. 4). This latter core question, stands at the heart of Palmer's vision who argues that "we teach who we are" (p. 1). ${ }^{4}$ Behind the diverse disciplines that teachers teach, he argues, there is a "self" to be known. Only based on such knowledge can a teacher know what he or she truly offers to their students as human beings. Most students are not going to be Mathematicians or Historians, nor will they excel in these disciplines. It seems then, that the main aim is excelling as "selves", cultivating Goodness, kindness, justice, inclusion - and this ought to be the top priority of education. How would we cultivate them without cultivating a deep knowing of the inner manifestations of these ethical dispositions? How can deep knowing emerge, without a deep engagement of the knower with the mind and body in which the knowing reside and within which it transforms into social engagement?

Looking at some broader initiatives, perhaps the most robust example in which the two epistemologies-ethics of education have been integrated in contemporary higher education is Brown University's BA program in contemplative studies. Students in this program study an interdisciplinary curriculum that revolves around contemplation. This includes courses in religion and Western philosophy in which students explore the origins of contemplative practices, as well as courses in which they study contemporary psychology and neuroscience of contemplation. All these could have neatly been compartmentalized within categories (a) and (b), had it not been for the fact that throughout their undergraduate studies, students engage in "labs" in which they practice the very contemplative practices about which they study in the theoretical courses. The idea of actual

\footnotetext{
${ }_{4}^{4}$ See Evelein \& Korthagen (2014) for additional approaches to reflection for teachers.
} 
meditation practice here is hardly some "soft" pedagogical approach. It is a fusion of the ethos of "serving science" with "know thyself", for students here are "encouraged to engage directly with these techniques without prior commitment to their efficacy. They then step back and appraise their experiences to gain a deeper appreciation of their meaning and significance" (Roth, 2006, p. 1789). Students thus attend to themselves deliberately, practicing diverse forms of meditation and receive academic credit for doing this. These practices develop what Roth calls a "critical first-person approach" - an ability to assess the contemplative practice in which they are engaged, the experience it invokes, and most importantly, the personal effects, and the meaning found or not found in it.

The ethos that emerges from these examples is a substantial return of "self". Barbezat and Bush identified that "students are actively dissuaded from finding themselves in what they are studying: all too often, students nervously ask whether they may use 'I' in their papers" (2014, p. 6). This is a clear sign that students have come to understand their interiority as a locus that lacks rigor and hence has no place within the construction of "knowledge" and meaning. At the same time, let us make no mistake. The word "I" does not bring rigor with it. Such rigor requires practice and discipline and this seems to be Roth's point. Just as one's skill as a researcher requires training in quantitative and qualitative methods, so does the skill of engaging critically with "self" require training. In Taylor's words this is based on "taking a stance of radical reflexivity or adopting the firstperson standpoint" in which, "we can turn [toward ourselves] and make this our object of attention, become aware of our awareness, try to experience our experiencing, focus on the way the world is for $u s^{\prime \prime}$ (1992a, p. 130). It is only by examining the experience of being moral from this "critical firstperson perspective", that we move from indoctrination, dogmatism or inadvertent compliance with social norm, into what can be justly called education in morality, agency and meaning (Alexander, 2005). Without reflection and introspection, our acts might be considered moral and even beneficial, 
yet we will never be able to justify them as such, nor will we be able to explain them to others so that they too, will act morally, or perhaps question our own acts as such.

Brown University's contemplative studies program is perhaps the most explicit example of unifying the two epistemology-ethics of higher education under one umbrella, however, this orientation is also found in other programs and research institutions that have been initiated in the past decade across the world, such as:

Simon Fraser University's MA in contemplative inquiry and approaches in education $(\mathrm{CA})^{5}$ Columbia University’s MA program in General Psychology, and mind-body spirituality (US) ${ }^{6}$ Bangor University center for mindfulness practice and research $(\mathrm{UK})^{7}$

IDC's MUDA Institute for Mindfulness, Science and Society (Israel) ${ }^{8}$

Stanford University's center for Compassion and Altruism Research and Education (US) ${ }^{9}$

The University of Wisconsin-Madison's Center for Healthy Minds (US) ${ }^{10}$

The above is an utterly partial list, nevertheless one that includes some very prestigious institutions. It is also important to acknowledge that attempts to integrate the two epistemologies-ethics of Higher Education can also be seen in even broader systematic endeavors. Colby et al's (2011) attempt to rethink undergraduate business education, might not necessarily be framed as "contemplative"; nevertheless, it conveys the ethos of this integration through other means and conceptualizations. They identify that College is "a prime moment for students $[\ldots]$ to question and redefine the sense of who they are" (p. 4), yet business students often view liberal arts courses in their curriculum - those, which may possibly engender such questioning - as unrelated to their

\footnotetext{
${ }^{5}$ https://www.sfu.ca/education/newsevents/foe-news/2013/december-2013/med-in-contemplative-inquiry-fall2014.html

${ }^{6}$ http://spiritualitymindbody.tc.columbia.edu/

7 https://www.bangor.ac.uk/mindfulness/

8 http://www.muda.idc.ac.il/he/home/

${ }_{9}$ http://ccare.stanford.edu/about/mission-vision/

10 http:/ / centerhealthyminds.org/
} 
profession. Colby et al. thus set out to provide a "vision of integration", which explains how and why a business graduate needs to deeply engage with such inner content, in order to be justly called an accomplished business professional. As argued earlier, the fact that the subject matter is "business" does not imply its severing from "self". The sense that "business" is impregnated with meaning and ethical commitments that lay far beyond the making of money, is invoked only through teaching practice that requires a deep attending to "self" and to its relationships with others.

The above examples may reveal that a pendulum, which has swung too far from "know thyself" to an epistemology-ethics of teaching that has been nullifying "self" from the lecture hall, is somewhat being pulled back to a more balanced place. Still, there is a long way go, for the above do not seem to reflect common teaching practice as the critical accounts mentioned in part one propose.

On this note, it is important to emphasize that when speaking of balance we need not think in quantitative terms. Those reading this paper, perhaps contemplating their own teaching ought not surmise that I am arguing that "serving science" and "know thyself" need to or can be fully balanced in each and every lesson and course. Nor can they be weighed under the same scale. One meaningful moment evoked intentionally by a teacher against a hundred others, which were spent with charts and Powerpoint presentations, may be all that it takes for "self" to be reclaimed in the lecture hall. Furthermore, sometimes such "self" moment is impossible to bring about without many "world" moments that precede it. The point made is ethical. It is about the meaning of higher education as it is shaped by what we do moment-by-moment when we teach.

\section{Concluding critical thoughts}

The argument proposed in this paper can be viewed as utterly provocative. It is likely to raise critical responses. One strong line of critique would challenge this paper's distinction between knowing 
"self" and knowing "world". I mentioned earlier that the two ought not to be viewed as separate, but I will also add that my alluding to thinking as theoretical physicists earlier, was not arbitrary. While it seems far removed from the act of teaching, such thinking often points to the very foundations of existence, exposing realities that are hard to detect otherwise. The argument made is not that "self" and "world" are separate as an ontological fact. Rather, I argue that there are ethical curricularpedagogical implications and practical benefits for teaching and education if we acknowledge that we can attend in or out distinctly to study our"selves" and (or in) the "world".

Other critical questions can challenge the aims of Higher Education as describe here, the place of academic achievements in this scheme, the feasibility of asking lecturers to become involved in students' lives and perhaps to evoke their emotional lives in ways that might be difficult to handle. Many issues of diversity and inequality are often safely kept at bay, when our meta-pedagogy effectively turns students out to hide a student from his own "self", and from his classmates. Are we willing to go to such difficult places? What does it mean if we are not willing to do so? Other concerns may point to the question of the origins of contemplative practices and their association with religious and spiritual beliefs. A dangerous line can easily be crossed between "know thyself", meaning and secular ethics, and the witting or unwitting proselytizing of certain beliefs by a charismatic lecturer.

These critical remarks and others that I have not mentioned here are crucial and valid. Some scholars discussed various fruitful solutions for some of these issues (Berila, 2015; Palmer et al., 2010). Notwithstanding, I do not pretend to suggest that there is anything simple or easy in the proposal of this paper. In fact, it was my intention to awaken an education that may have been avoiding a complication without which it fails its purpose. "Serving science" is by all means important, yet the educational quest is always broader and our ethics of teaching that treats "self's" "inner depth" must not be compromised. There seem to be teaching practices that can integrate 
both so that the "two" will be experienced as mutually reinforcing each other toward an Education that will justly be called, Higher.

\section{$\underline{\text { References }}$}

Alexander, H. (2005). Education in ideology. Journal of Moral Education, 34(1), 1-18.

Barbezat, D., \& Bush, M. (2014). Contemplative practices in higher education: Powerful methods to transform teaching and learning. San Francisco, California: Jossey-Bass.

Berila, B. (2015). Integrating mindfulness into anti-oppression pedagogy: Social justice in higher education. New York: Routledge.

Biesta, G. (2009). Good education in an age of measurement: On the need to reconnect with the question of purpose in education. Educational Assessment, Evaluation and Accountability, 21(1), $33-46$.

Bok, D. (2009). Universities in the marketplace: The commercialization of higher education. New Jersey: Princeton University Press.

Bruner, J. (1977). The process of education (Revised edition). Cambridge: Harvard University Press.

Colby, A., Ehrlich, T., Sullivan, W. M., \& Dolle, J. R. (2011). Rethinking undergraduate business education: Liberal learning for the profession. San Francisco: Jossey-Bass.

Davidson, R., Dunne, J., Eccles, J. S., Engle, A., Greenberg, M., Jennings, P., ... Vago, D. (2012). Contemplative practices and mental training: prospects for American education. Child Development Perspectives, 6(2), 146-153.

Denzin, N. K., \& Lincoln, Y. (Eds.). (2011). The SAGE handbook of qualitative research (4 edition). Thousand Oaks: SAGE Publications, Inc. 
Dearden, R. F., Hirst, P. \& Peters, R. S. (Eds.) (1972). Education and the development of reason. London: Routledge \& Kegan Paul.

Deresiewicz, W. (2014). Excellent sheep: The miseducation of the American elite and the way to a meaningful life. New York, NY: Free Press.

Dewey, J. (1997). How we think. Mineola, N.Y.: Dover Publications.

Eisner, E. W. (1994). The educational imagination: On the design and evaluation of school programs (3rd ed.). New York: Macmillan.

Ergas, O. (2017a). Reconstructing 'education' through mindful attention. Positioning the mind at the center of curriculum and pedagogy. London: Palgrave Macmillan.

Ergas, O. (2017b). Schooled in our own minds: Mind wandering and mindfulness in the makings of the curriculum. The Journal of Curriculum Studies (ahead of print).

Evelein, F. G., \& Korthagen, F. A. J. (2014). Practicing core reflection: Activities and lessons for teaching and learning from within (1st ed.). New York, NY: Routledge.

Farb, N. A. S., Segal, Z. V., \& Anderson, A. K. (2013). Mindfulness meditation training alters cortical representations of interoceptive attention. Social Cognitive and Affective Neuroscience, $8(1), 15-26$.

Frankl, V. E. (1985). Man's search for meaning. New York: Simon and Schuster.

Garland, E. L., Farb, N. A., Goldin, P. R., \& Fredrickson, B. L. (2015). Mindfulness broadens awareness and builds Eudaimonic meaning: A process model of mindful positive emotion regulation. Psychological Inquiry, 26(4), 293-314.

Gilead, T. (2012). Education and the logic of economic progress. Journal of Philosophy of Education, 46(1), 113-131.

Gunnlaugson, O., Sarath, E., Scott, C., Bai., H. (2014). Contemplative learning and inquiry across disciplines. Albany: State University of New York Press. 
Hadot, P., \& Davidson, A. I. (1995). Philosophy as a way of life: Spiritual exercises from Socrates to Foucault. Malden, MA: Blackwell.

Immordino-Yang, M. H. (2016). Emotion, sociality, and the brain's default mode network: Insights for educational practice and policy. Policy Insights from the Behavioral and Brain Sciences, 3(2), 211219.

James, W. (1983). Talks to teachers on psychology and to students on some of life's ideals. Cambridge, Mass.: Harvard University Press.

James, W. (2007). The principles of psychology. New York, NY: Cosimo.

Langer, E. J. (1997). The power of mindful learning. Reading, MA, US: Addison-Wesley/Addison Wesley Longman.

Lelwica, M. M. (2009). Embodying learning: Post-Cartesian pedagogy and the academic study of religion. Teaching Theology \& Religion, 12(2), 123-136.

Levit-Binnun, N., \& Tarrasch, R. (2014). Relation between contemplative exercises and an enriched psychology students' experience in a neuroscience course. Frontiers in Psychology, 5(1296), 116.

Levy, D. M. (2016). Mindful tech: How to bring balance to our digital lives. New Haven: Yale University Press.

Lewis, H. (2007). Excellence without a soul: Does liberal education have a future? (1st ed.). New York: PublicAffairs.

Lin, J., Oxford, R. L., \& Brantmeier, E. J. (2013). Re-envisioning higher education: Embodied pathways to wisdom and social transformation. Toronto: Information Age Publishing, Inc.

Magee, R. V. (2016). The way of ColorInsight: Understanding race and law effectively through mindfulness-based ColorInsight practices. The Georgetown Law Journal of Modern Critical Race Perspectives, (Spring), 1-59. 
Nietzsche, F. (1997). Nietzsche: Untimely meditations. (D. Breazeale, Ed., R. J. Hollingdale, Trans.) (2nd ed.). Cambridge ; New York: Cambridge University Press.

Palmer, P. (1983). To know as we are known: A spirituality of education (1st ed.). San Francisco: Harper \& Row.

Palmer, P. (1998). The courage to teach: Exploring the inner landscape of a teacher's life (1st ed.). San Francisco: Jossey-Bass.

Palmer, P., Zajonc, A. \& Scribner, M. (2010). The heart of higher education: A call to renewal (1st ed.). San Francisco: Jossey-Bass.

Perkins, D. (1999). The many faces of Constructivism. Educational Leadership, 57(3), 6-11.

Phillips, D. C. (1995). The good, the bad, and the ugly: The many faces of constructivism. Educational Researcher, 24(7), 5-12.

Pinar, W., \& Grumet, M. R. (2014). Toward a poor curriculum (3rd ed.). Kingston, NY: Educator's International Press, Inc.

Roderick, L., \& Merculieff, I. (2013). Stop talking: Indigenous ways of teaching and learning and difficult dialogues in higher education. Anchorage, Alaska: University of Alaska Anchorage.

Rodgers, C. (2002). Defining reflection: Another look at John Dewey and reflective thinking. Teachers College Record, 104(4), 842-66.

Roeser, R. W., \& Peck, S. C. (2009). An education in awareness: Self, motivation, and self-regulated learning in contemplative perspective. Educational Psychologist, 44(2), 119-136.

Rorty, R. (2009). Philosophy and the mirror of Nature. New Jersey: Princeton University Press.

Roth, H. D. (2006). Contemplative studies: Prospects for a new field. Teachers College Record, 108(9), $1787-1815$.

Schön, D. A. (1987). Educating the reflective practitioner: Toward a new design for teaching and learning in the professions. San Francisco, California: Jossey-Bass. 
Schwab, J. J. (1969). The practical: A language for curriculum. The School Review, 78(1), 1-23.

Shusterman, R. (2012). Thinking through the body. Cambridge, UK: Cambridge university press.

Simmer-Brown, J. (2009). The question is the answer. Religion \& Education, 36(2), 88-101.

Solbrekke, T. D. \& Helstad, K. (2016). Student formation in higher education: Teaching approaches matter. Teaching in Higher Education, 21(8), 962- 977.

Tang, Y.-Y., Hölzel, B. K., \& Posner, M. I. (2015). The neuroscience of mindfulness meditation. Nature Reviews Neuroscience, 16(4), 213-225.

Taylor, C. (1992a). Sources of the self: The making of the modern identity. Cambridge, UK: Cambridge University Press.

Taylor, C. (1992b). The ethics of authenticity. Cambridge, MA: Harvard University Press.

Wallace, B. A. (2000). The taboo of subjectivity: Toward a new science of consciousness. New York: Oxford University Press.

Whitehead, A. (1967). The aims of education and other essays. New York: Free Press.

Zajonc, A. (2006). Love and knowledge: Recovering the heart of learning through contemplation. Teachers College Record, 108(9), 1742-1759.

Zenner, C., Herrnleben-Kurz, S., \& Walach, H. (2014). Mindfulness-based interventions in schools_a systematic review and meta-analysis. Frontiers in Psychology, 5, 1-16. 